\title{
DEVELOPMENT OF AREAS AND PUBLIC PURPOSE INVESTMENTS IN SUBURBAN TERRITORIES
}

\author{
Ada Wolny, PhD \\ Faculty of Geodesy and Land Management (associate) \\ University of Warmia and Mazury in Olsztyn \\ e-mail: adawolny@wp.pl
}

\author{
Alina Źróbek - Różańska, PhD \\ Faculty of Economics \\ University of Warmia and Mazury in Olsztyn \\ e-mail: alina.zrobek@uwm.edu.pl
}

\section{Ryszard Źróbek, Prof.}

Faculty of Geodesy and Land Management

University of Warmia and Mazury in Olsztyn

e-mail: rzrobek@uwm.edu.pl

\section{Marek Piotrowski, M.Sc.}

Faculty of Geodesy and Land Management

University of Warmia and Mazury in Olsztyn

e-mail:alimar@uwm.edu.pl

Jens Frey, M.Sc.

DB ProjektBau GmbH

e-mail:freyj@gmail.com

\section{Abstract}

Suburban areas are subjected to particularly strong investment pressure, thus facing the challenge arising from the need to impose new spatial order. Satisfying the residents' expectations by implementing necessary technical and social infrastructure becomes a priority. Therefore, public investments play an important role in suburban areas.

The article discusses the role of public purpose goals and their achievement using a case study which encompassed the outskirts of Olsztyn and consisted of detailed analyses of two gminas (communes) adjacent to the city. The research covered the time period from 2006 to 2010. The relationship between the development of housing functions in a suburban area and the location of public purpose investments such as technical and social infrastructure has been documented. The execution of public purpose projects is a follow-up of the development strategies prepared for the gminas where public investments are shown as a stimulant of suburban development. It has been demonstrated that decisions permitting such investments to be carried out are issued in response to the needs of the local community and investors moving to suburban territories.

Key words: public investment, development, priorities, investments, infrastructure, suburban areas.

JEL Classification: R58, R53, C26, O20.

Citation: Wolny A., Źróbek - Różańska A., Źróbek R., Piotrowski M., Frey J., 2014, Development of areas and public purpose investments in the suburban territory, Real Estate Management and Valuation, vol. 22, no. 2, s. 86-97.

DOI: $10.2478 /$ remav-2014-0020 


\section{Introduction}

Suburban areas are exposed to particularly strong investment pressure due to the growth of cities and their expansion beyond urban limits. Such municipalities face the challenge of imposing spatial order in areas experiencing intensive development. On the other hand, lying in the proximity of a city is an important growth stimulant for suburban gminas.

The influx of urban residents to the outskirts of the city, the subsequent construction of town-like buildings, and the growing number of businesses locating some or all their premises in the suburbs are a challenge faced by local governments, which are responsible for meeting the growing needs of communities.

One of the priorities in areas subjected to the pressure of urbanization is to satisfy the local community's demand for a technical and social infrastructure. Public purpose investment projects are therefore essential. Although they are planned and executed on a local level, many have a supra-local character.

This article discusses the role of public purpose investments and shows how they are executed. The data for our analysis were collected by investigating the suburbs of Olsztyn, the capital of the voivodeship (province) and main urban centre in Warmia and Mazury. Detailed investigations comprised two communities lying in the nearest proximity of the city.

\section{Public purpose in spatial management and real estate management}

In the light of the Real Property Management Act of 21 August 1997 (Journal of Law 2010, No 102, item 651, with subsequent amendments), public purposes are defined as actions mentioned in Art. 6 of the aforementioned Act. There are a finite number of them until further cases are added.

What is more, by passing another legal act the legislator is allowed to clarify how a public purpose should be understood. No other subject is authorized to classify a given investment project as belonging to the group of public purpose projects. Public purposes, however, can be defined in separate legal acts, for example the Act of 10 April 2003 on Specific Procedures for Preparation and Execution of Investments in Public Roads (Journal of Law of 2008, No 193, item 1194, with subsequent amendments).

Referring to the contents of Art. 6 of the Real Property Management Act, it should be noted that a public purpose is, for example, the construction and maintenance of public utility constructions and facilities, including technical infrastructure and the broadly understood transportation and communication infrastructure, as well as zoning land for the sake of constructing such buildings, facilities or infrastructure.

What all public purposes defined in the Real Property Management Act share is their common availability and intended use by the general public. This understanding of a public purpose is confirmed by judicial decisions, for example the decision of the Provincial Administration Law Court of 7 March 2007 (register no IV SA/Wa2037/06), in which it was stated that "the notion of a public purpose means the purpose concerning the general public, serving needs of all people, indented to be used (made available to) by all people. The deployment of principles and procedure envisaged for localization of public purpose investments therefore depends on whether planned investments which require appropriate permits comprise 'a public element.'" The performance of public goals serves to satisfy the needs of a local community (e.g. by constructing a network of water pipes), but can also meet the expectations of larger populations, e.g. the inhabitants of a whole poviat (district), voivodeship or even the entire country (building expressways or an airport).

When a location is chosen for a public purpose investment project, a given parcel of land is zoned out for public purposes in a local spatial development plan or through administrative channels after an investor has submitted an application to the head of the local government, in the mode envisaged by the Act on Spatial Planning and Development of 27 March 2003 (Journal of Law of 2012, No 951, item 647 with subsequent amendments). This regulation governs public purpose investment projects which are assigned a local (municipal) or supra-local meaning (important on the level of a poviat, voivodeship, or country).

The process of defining a land use of real estate as serving public purposes, or else the process of determining the location of a public purpose investment project, both take into account the social and economic conditions, as well as the provisions of legal regulations, which has been illustrated in figure 1. 


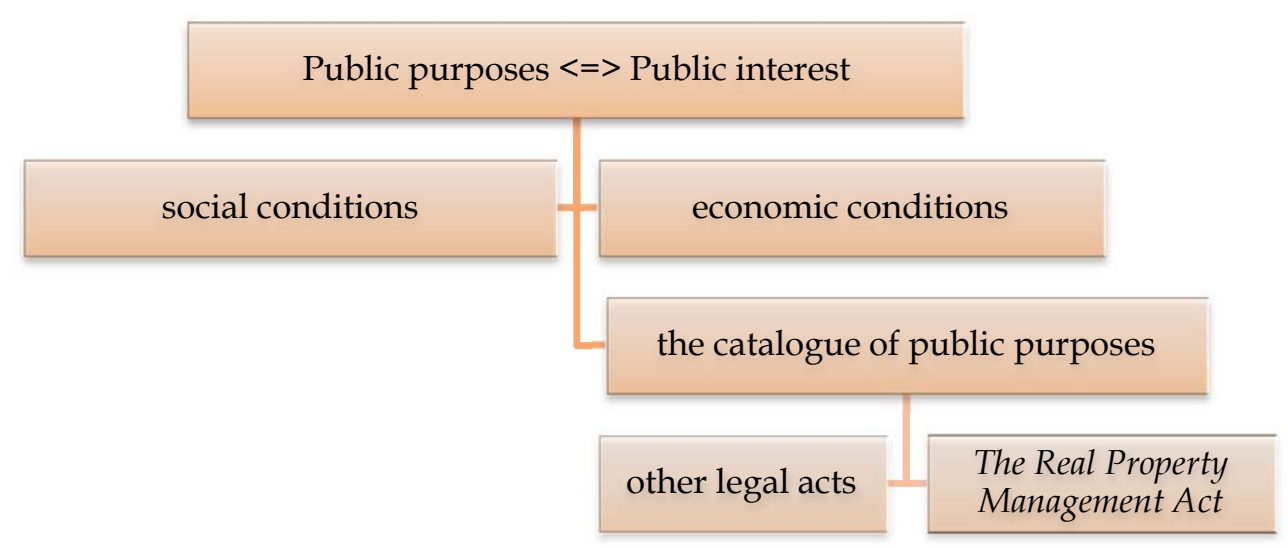

Fig. 1 Conditions set for the execution of a public purpose investment project. Source: ŹRÓBEK R., ŹRÓBEK S. (2007).

If the administrative mode is chosen, the statutory time limit for issuing a decision on a public purpose investment is set at two months. If a public purpose investment is assigned an important role on the level of a whole voivodeship or on a national level, after the statutory time limit has elapsed fruitlessly, an appropriate decision is passed by the voivode (provincial governor).

\section{Public purpose in the development strategy of a gmina}

The local government in any gmina or municipality is an independent subject, which is granted a specific range of freedom in making decisions about the development of the governed area and property of the gmina, and in the performance of public tasks. The responsibilities and competences of local authorities include actions undertaken for public interest and to satisfy local residents' needs in the social, economic, ecological, residential and spatial management spheres. The quality of a local self-government is manifested by the success it achieves in satisfying these needs with the limited public funds available. Creating an environment in which a local community lives is inseparable from developing a given municipality (PYTLAK 2011 after PARYSEK 2001).

The gmina self-government should base its actions on a long-term development strategy, treated as a collection of guidelines for local authorities, and set targets as well as ways of attaining these targets, adjusted to the situation in the nearer and further surroundings. The strategy should include these social and economic phenomena which can be governed by the local authorities, that is the ones which the local government can shape and for which it bears responsibility (PYTLAK 2011 after GORZELAK, JAŁOWIECKI 2000).

Thus, the strategy of the development of a gmina is an action plan designed for a long time. First of all, it defines strategic aims of the gmina's development. These strategic aims are further developed into operational goals and tasks for implementation. The underlying purpose of creating development strategies is to attain an optimal level of satisfying the local community's needs. The development strategy is a base which the long-term policy of a gmina relies on in the spheres of socio-economic life, the infrastructure, spatial management, ecology and cultural heritage. Local authorities try to shape the attitudes of individual business enterprises in such a way as to achieve the aims set in their development strategy (TROJANEK 1996).

Considering the above features of a development strategy, the role of a gmina as a subject responding to the needs of a local community should be emphasized. Satisfying communal demands manifests itself in the development strategy by planning the execution of public purpose investments, both in the general form (as the development of technical infrastructure) and in a more detailed manner (as specific tasks under the framework of operational aims).

A strategy as an action plan takes into account the responsibility to perform public tasks borne by local governments, as defined by the Act on Local Government of 8 March 1990 (Journal of Law of 2001, No 142 item 1591 with subsequent amendments). The execution of own tasks by a gmina defined by Article 7 of the Act on Local Government involves the completion of public investment projects, in compliance with the procedure specified in the Act on Spatial Planning and Development. A public aim investment is therefore a response to the local community's demands, a form of pursuing the gmina's own tasks, and a factor stimulating the development of a given area. 
In analyses which directly involve the development strategies of gminas, the following distinguishing features of public purposes must be taken into consideration (ALTERMAN 2007, UN 2000, SEE 2002):

a) the permitted time frame for implementing the public purpose,

b) the number of beneficiaries - the community which will use public buildings and facilities,

c) a change of the initial purpose to a new one if, for some objective reasons, the execution of a previous task has become pointless,

d) the participation of other local government entities in the execution of the task,

e) the actions a gmina undertakes to support the execution of a public purpose and the applicable procedures when this purpose is not implemented.

\section{Priorities in the development of suburban areas, exemplified by chosen gminas}

In order to indicate what priorities guide local authorities while designing development strategies, the authors analyzed the contents of the strategies of two suburban gminas (Dywity and Stawiguda, in the Voivodeship of Warmia and Mazury). Figure 2 illustrates the location of the gminas relative to the capital city of the voivodeship.

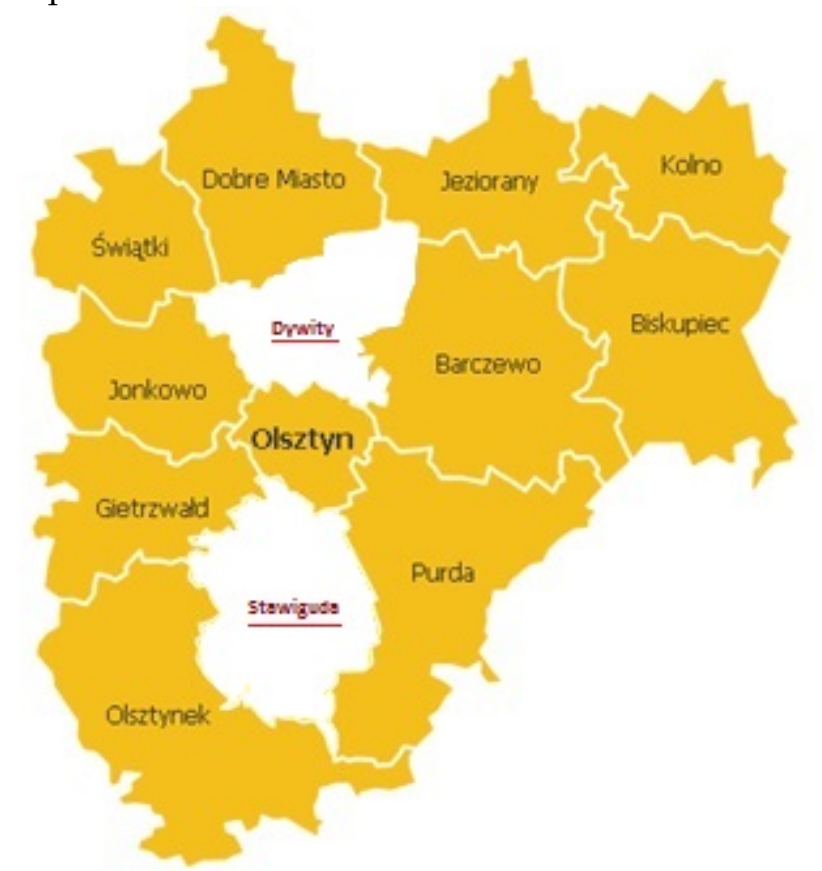

Fig. 2. Location of gminas in the Poviat of Olsztyn. Source: own study, based on http://www.kupsprzedaj.pl/Content/Maps/polska/warminsko_mazurskie/olsztynski.gif

The priorities in the development of the gminas of Dywity and Stawiguda have been identified based on the main and specific aims defined in two documents:

a) The Development Strategy of the Gmina of Dywity until 2020. GEOPROFIT, 2010, Warszawa,

b) The Development Strategy of the Gmina of Dywity for the years 2008-2015. CDEF, 2008, Olsztyn.

The development strategy of the Dywity gmina dates back to 2010. It describes the development strategy until the year 2020. The principal aim of this strategy is to raise the importance of the gmina as a highly attractive residential and business destination lying in the metropolitan area of Olsztyn. The greater appeal of the gmina as a place for conducting business is intended to strengthen the local economy, provide more jobs, and give access to different services (GEOPROFIT 2010).

Operational aims, important from the point of view of potential investors, have also been defined. They include the provision of modern, safe and commonly accessible technical infrastructure. The specific actions are the development of the water and sewage network as well as household wastewater treatment systems, the provision of access to information society infrastructure, and the further growth of municipal services.

Another operational goal indicated in the strategy is to ensure a broad range of public services to the local community. Public services include, in particular: child care and education, health services, 
and culture, recreation and relaxation services and facilities. The implementation of this task involves, for example, subsidies granted to private preschools, the expansion and refurbishment of school facilities, building bicycle paths, and the spatial management of the shores of Lake Wadacg.

Additionally, in order to attain a following operational goal, i.e. high accessibility to the transportation network, the role of which as a driving force behind the gmina's development has been emphasized, tasks such as the modernization of existing roads and the development of public transport have been pinpointed.

The analysis of the development strategy for the gmina of Dywity until 2020 shows that this community perceives its opportunities for growth as developing business and attracting entrepreneurs. Through actions oriented towards developing social and technical infrastructure, as well as promotional activities, the authorities of gmina Dywity wish to gain a competitive edge over the other gminas adjacent to Olsztyn.

The analysis also comprised the development strategy designed by the gmina of Stawiguda. This document was drawn in 2008 and covers the time period until 2015. The main aim defined in the strategy for the gmina of Stawiguda is to take full advantage of its location and natural assets in order to enhance the quality of life of the local residents and to ensure the sustainable development of the economy, as well as the tourism and hospitality industry. Specific targets were defined for the sake of reaching the general aim, among which the development of technical infrastructure ranked first, which would make the gmina a more attractive place to live and invest in. Under this task, building waterworks and sewerage systems is treated as a priority, because it will help to improve living conditions, develop industrial and commercial land plots and protect the natural environment. Other detailed tasks include waste management and recycling, better public transport, better traffic flow through roads crossing the gmina, building new car parks and using renewable energy resources.

Another task which is important to the gmina's development is the provision of high quality education and culture. The detailed activities distinguished under this task include the preservation of the cultural heritage, promotion of culture and local traditions, dissemination of information technology by creating areas with free access to the internet, and modernization of culture and sports venues and facilities.

This strategy contains a description of another goal, which involves improving health care, public safety, social security, fire protection and nature conservation. This goal is to be achieved by promoting a healthy lifestyle and preventing addictions among the residents of the gmina, organizing and supporting a system of family and child care, and creating good conditions for the rehabilitation of the disabled and care of the elderly.

Analogously to Dywity, the gmina of Stawiguda also intends to attract investors. Both gminas see their opportunity for development in their location near the capital city of the voivodeship, and at the intersection of major transportation routes in the region. This location means that the gminas have a better chance of developing local entrepreneurship. Moreover, owing to the migration of the Olsztynbased population to the outskirts of the city, suburban communities can expand the total area zoned for residential purposes.

For potential investors, the most important aims set by local authorities and expressed in strategic documents are the ones connected to the development of the technical and social infrastructure. When expanding a local grid of roads, for example, the development of technical facilities and the range of social services available are the most fundamental conditions considered when choosing a location for an investment project. These are also the factors most frequently assessed when making a decision about the location of a public purpose investment in the two analyzed gminas: Stawiguda and Dywity.

Development strategies are no more than just long-term plans, hence our analysis was expanded to encompass the actual actions pursued by the gminas to accomplish public aims, and in particular, decisions to localize public purpose investments. This analysis is a medium-term one, as it covers a five-year time period.

\section{Pursuit of public purpose investments in the gminas of Dywity and Stawiguda in 2006-2010}

The outskirts of any larger town tend to be subjected to dynamic social, economic and spatial changes. Suburban districts exposed to particularly strong investment pressure must face the challenge of imposing spatial order over the areas where investors are exceptionally active. Sprawling cities and the influx of urban dwellers to suburban areas typically involve rising expectations regarding the 
social and technical infrastructure of a given area.

Public administration organs respond to these needs by making changes in the spatial order to ensure that the demanded amenities, facilities and networks will be constructed. They approve local spatial development plans, in which provisions are made to secure land for roads, communication systems, technical facilities, and public service buildings. Noteworthy are public purpose investments approved through administrative decision channels, as these respond to public needs directly and instantly. The analysis, therefore, comprised decisions on the location of public purpose investments in the two gminas passed in 2006-2010. The results are presented in table 1, where the number of the issued decisions is juxtaposed with the statistical data for all of Poland.

Table 1

Decisions on the location of public purpose investments in the gminas of Dywity and Stawiguda in 2006-2010

\begin{tabular}{|c|c|c|c|c|c|}
\hline \multirow{3}{*}{ Specification } & \multicolumn{5}{|c|}{ Values in the analyzed period } \\
\hline & 2006 & 2007 & 2008 & 2009 & 2010 \\
\hline & number & number & number & number & number \\
\hline & \multicolumn{5}{|c|}{ in total countrywide } \\
\hline & 26,360 & 24,991 & 26,943 & 26,072 & 24,399 \\
\hline & \multicolumn{5}{|c|}{ on average in a single gmina } \\
\hline & 11 & 10 & 11 & 11 & 10 \\
\hline & \multicolumn{5}{|c|}{ in the gmina of Dywity } \\
\hline \multirow{3}{*}{$\begin{array}{l}\text { Decision on location } \\
\text { of a public purpose } \\
\text { investment }\end{array}$} & 36 & 24 & 45 & 39 & 61 \\
\hline & \multicolumn{5}{|c|}{ in the gmina of Stawiguda } \\
\hline & 21 & 21 & 29 & 31 & 32 \\
\hline
\end{tabular}

Source: own study, using data from the Polish Central Office of Statistics.

Decisions on the location of public purpose investments were passed in gmina Stawiguda two to three times more often than in an average Polish gmina. Moreover, a rising tendency has been observed, which proves that the local authorities are genuinely dedicated to the performance of public purpose investments which satisfy the needs of local residents.

In the gmina of Dywity, such decisions are passed much more often than the average for the whole country. The number of the aforementioned decisions is anywhere from two to six times higher (in 2010) than in an average Polish municipality. The number of decisions on the location of public purpose investments increased steadily year after year (except for the year 2007). This proves that the local authorities are determined to achieve public aims. The high number of such decisions is a positive finding. It should be emphasized that during the analyzed time period, more decisions were passed in the gmina of Dywity than in Stawiguda. For the five years under study, the difference in the total number of decisions was found to be $35 \%$.

In the subsequent stage of the analysis, we focused on specific public aims that the above decisions dealt with. Figures 3 and 4 show the percentages of the types of public purpose investments the location of which was set by decisions passed by the executive administration organs in the gminas of Dywity and Stawiguda.

As shown in figure 3, the construction and modernization of the technical infrastructure networks, buildings and facilities was the most common type of public purpose investment. Over $36 \%$ of the decisions passed were to provide the general public with electricity. The second most popular goal was to provide gas (nearly 23\%) and water to households (13\% of the cases). As opposed to the investments in waterworks, the total investment into sewerage and wastewater systems, both for sewage and for rainwater, accounts for just $6 \%$ of all cases. The same percentage was calculated for decisions on investments in transportation systems (construction or modernization of roads, construction of re-designed junctions, new sidewalks), which seems to be an insufficient number of decisions considering the priorities established by the gmina. Decisions concerning investments in telecommunication facilities constituted the smallest share $(3 \%)$, but this can be explained by the ongoing implementation of new transmission technologies.

With respect to social infrastructure, i.e. public service buildings and amenities, $9 \%$ of all location decisions included such goals (e.g., the modernization or expansion of school buildings, preschools, a 
fire station and a health centre).

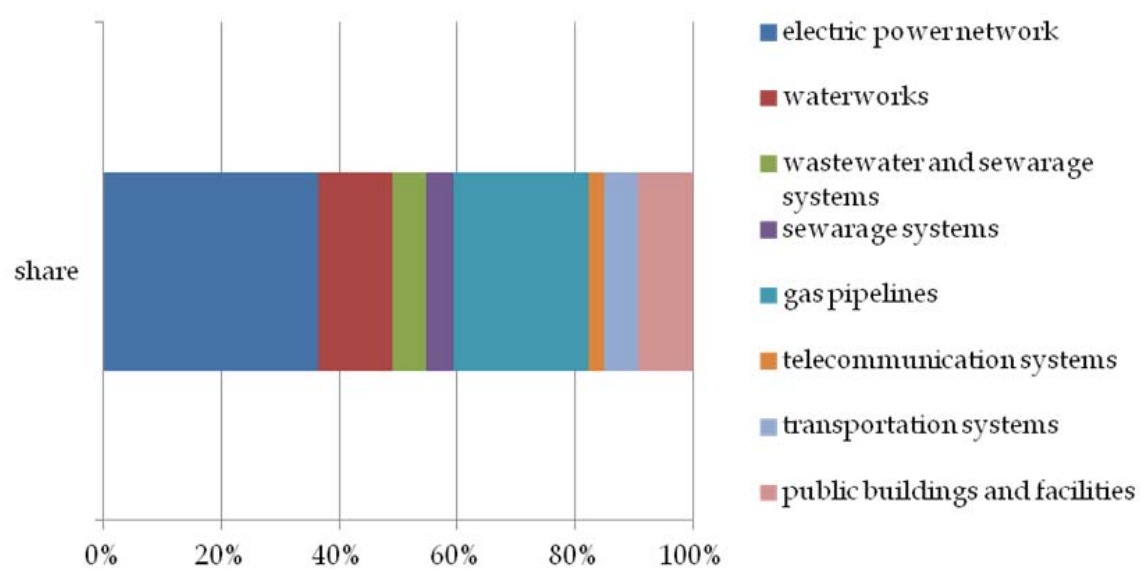

Fig. 3. Public purposes found in decisions passed in the gmina of Dywity in 2006 - 2010. Source: own study.

The relative shares of public purpose investments pursued in the gmina of Stawiguda have also been determined (fig. 4). The public demand for electricity (39\% of all decisions) and gas (26\%) were satisfied most often. Over $11 \%$ of the decisions concerned the waterworks and sewerage systems, with investments the sole purpose of which was to supply water or to collect wastewater and rainwater contributing to half of this percentage (fig. 4). Telecommunication facilities were considered more often than in Dywity (over 5\% of all decisions), but changes in the transportation system were implemented less frequently (3\% of all cases). With such statistics, the rising expectations of new residents commuting to this town cannot be fully satisfied.

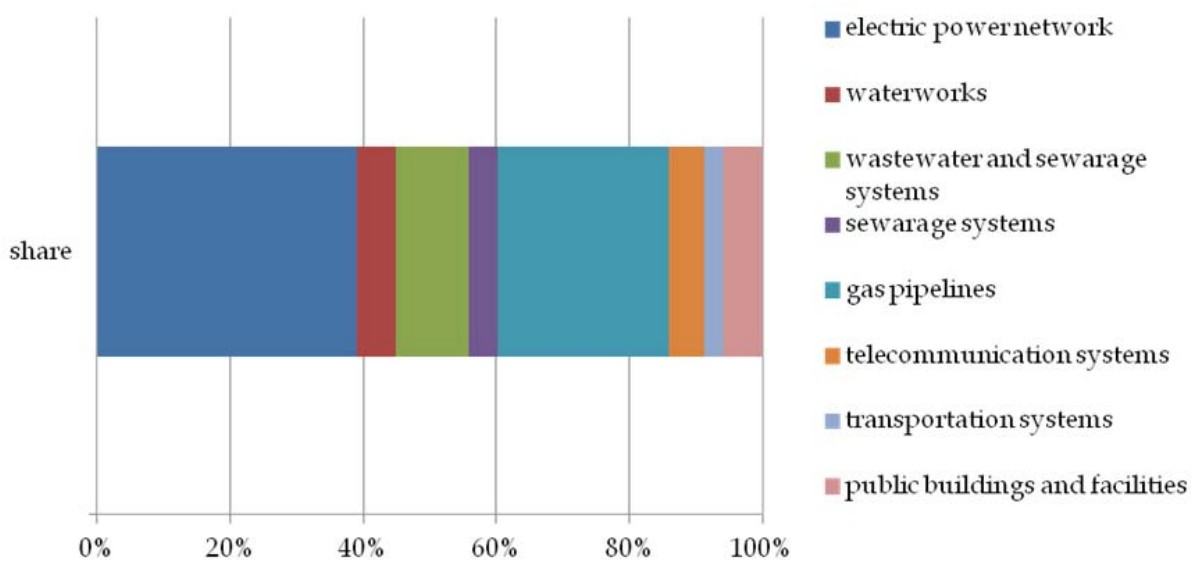

Fig. 4. Public purposes found in decisions passed in the gmina of Stawiguda in 2006 - 2010. Source: own study.

As illustrated by fig. 4, location decisions on public service buildings made up fewer than $6 \%$ of the total number of all such decisions. The approved investment projects include building civic centres as well as the modernization of a secondary school building.

The above analysis of the decisions on the location of public purpose investments shows that most of such decisions concern land development, i.e. the construction of technical infrastructure for developing residential areas and business enterprises. Some of these facilities are linear (e.g. gas pipes, waterworks). In order to determine the links between the public purpose investments carried out in the gminas of Dywity and Stawiguda with the development of built-up areas, spatial analyses were performed to match the localizations of the above public aim projects and the directions in the expansion of suburban housing estates and commercial premises. 


\section{Location of the technical and social infrastructure versus the expansion of developed areas in the suburban environs}

In order to determine spatial relationships, data were collected about all of the zoned land parcels which were the subject of decisions on the location of a public purpose investment in the gminas of Dywity and Stawiguda, including the plot numbers. It should be remembered that location decisions may pertain to one or several numbered lots (especially in the case of linear type investments).

The collected primary data were transformed by assigning universal numbers to the parcels, and then imported to the Saga Gis program, where this information was visualized against a cartographic background, which included the location and boundaries of land plots in the two gminas. The program was run to perform quatric kernel estimation. Data were assigned to the centroids of the plots to which the location decisions had been applied. The analyses enabled us to determine regions characterized by a special concentration of public purpose location decisions. Distributions of the density of cases were determined for the gminas of Dywity (fig. 5) and Stawiguda (fig. 6).

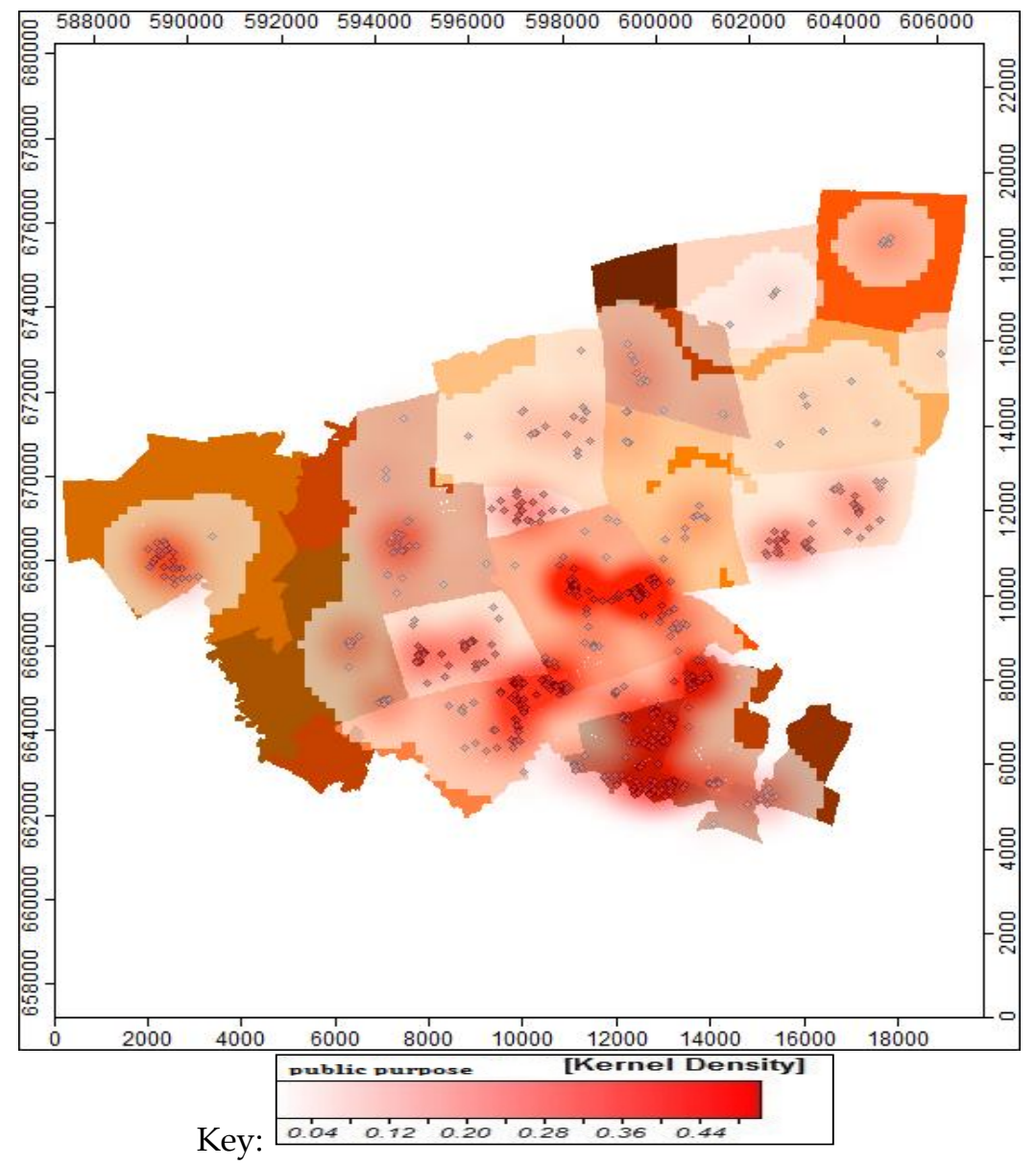

Fig. 5. Distribution of the density (Quatric Kernel) of decisions on the location of public purpose investments. Source: own study.

Figure 5 leads to the conclusion that areas lying in the south and in the centre of the gmina are characterized by a higher density of cases. The highest density of the analyzed cases was observed in the eastern part of the Dywity cadastral district, the centre of the Różnowo district, and in Kieźliny. The highest density in relation to the area of the cadastral district occurred in Kieźliny. The two later districts, Kieźliny and Dywity, border Olsztyn to the south, which may induce ever more intensive space transformations, causing an increasing demand for infrastructure supporting newly created buildings. 


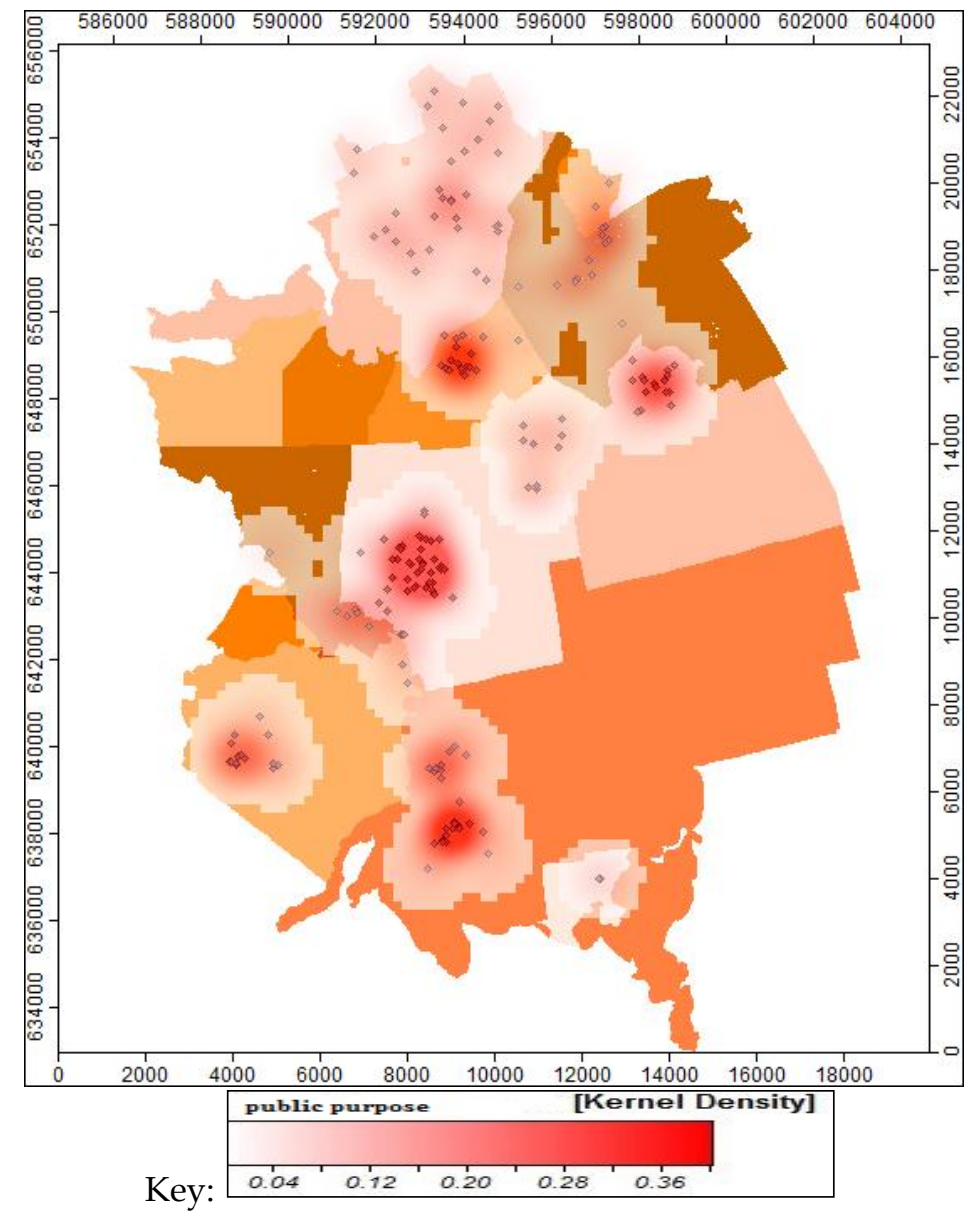

Fig. 6. Distribution of the density (Quatric Kernel) of decisions on the location of public purpose investments in the gmina of Stawiguda in 2006 - 2010. Source: own study.

Figure 6 demonstrates that the areas with a higher density of cases are those situated in the northern, central and southern parts of the gmina of Stawiguda, that is on the borderline between the cadastral districts of Ruś and Bartag, in the western part of the district of Pluski, and within the districts of Stawiguda and Dorotowo. A considerable number of cases were also noticed in the district of Tomaszkowo, in the north-eastern part of the gmina. Worth noticing is the fact that the areas with a high concentration of cases are found in the cadastral districts which border Olsztyn to the north (Bartagg) or lie quite near the town and along the main road leading to Olsztyn.

In both gminas, cadastral districts with the highest concentration of decisions on the location of public purpose investments were distinguished. Next, data from these districts were gathered, including the number of issued decisions on land development conditions, as well as the number of and total area covered by local spatial development plans. The aim was to verify the relationship between public purpose investments carried out in a gmina and the development of buildings (mainly residential ones). This information has been presented in tables 2 and 3 .

Table 2

Issued decisions on land development and management conditions in the gminas of Dywity and

Stawiguda in 2006 - 2010

\begin{tabular}{|c|c|c|c|c|c|c|}
\hline \multirow[b]{2}{*}{ Specification } & \multicolumn{6}{|c|}{ Values in the analyzed period } \\
\hline & 2006 & 2007 & 2008 & 2009 & 2010 & Total \\
\hline \multirow{6}{*}{$\begin{array}{c}\text { Number of } \\
\text { decisions about } \\
\text { land development } \\
\text { conditions }\end{array}$} & \multicolumn{6}{|c|}{ in the gmina of Stawiguda } \\
\hline & 67 & 97 & 49 & 73 & 92 & 378 \\
\hline & \multicolumn{6}{|c|}{ Stawiguda } \\
\hline & 20 & 36 & 13 & 23 & 24 & 116 \\
\hline & \multicolumn{6}{|c|}{ Dorotowo } \\
\hline & 10 & 19 & 12 & 8 & 5 & 54 \\
\hline
\end{tabular}




\begin{tabular}{cccccc}
\multicolumn{6}{c}{ Bartąg } \\
\hline 12 & 4 & 6 & 4 & 11 & 37 \\
\hline \multicolumn{7}{c}{ in the gmina of Dywity } \\
\hline 156 & 232 & 282 & 213 & 169 & 1052 \\
\hline \multicolumn{6}{c}{ Dywity } \\
\hline 21 & 42 & 24 & 25 & 18 & 130 \\
\hline \multicolumn{7}{c}{ Kieźliny } \\
\hline 21 & 32 & 37 & 30 & 25 & 145 \\
\hline \multicolumn{7}{c}{ Różnowo } \\
\hline 10 & 23 & 59 & 18 & 20 & 130 \\
\hline
\end{tabular}

Source: own study, based on data in communal registers of decisions and the Central Statistical Office.

Table 2 shows that extremely high investment activity, expressed by the number of issued decisions regarding land development conditions, could be observed in the districts of Dywity, Kieźliny, Różnowo and Stawiguda, where the number of issued decisions during the time period encompassed by our research exceeded 100. In the districts of Dorotowo and Bartagg, the respective numbers were much lower (table 3).

Table 3

Local plans in the gminas of Dywity and Stawiguda in force at the end of 2010

\begin{tabular}{lcc}
\hline & \multicolumn{2}{c}{ Local spatial development plans (in 2010) } \\
\cline { 3 - 3 } \multicolumn{1}{c}{ Register unit/district } & area [ha] & number \\
\cline { 3 - 3 } gmina of Dywity & 2,253 & 33 \\
\hline Dywity & & 12 \\
\hline Kieźliny & $\mathrm{x}$ & 3 \\
\hline Różnowo & 1,915 & 6 \\
\hline gmina of Stawiguda & & 63 \\
\hline Stawiguda & & 7 \\
\hline Bartąg & $\mathrm{x}$ & 13 \\
\hline Dorotowo & & 4 \\
\hline
\end{tabular}

Source: own study, based on records in the gminas and the Central Statistical Office.

The above juxtaposition shows that of the 33 binding local spatial development plans in the gmina of Dywity, 12 cover lots which belong to the district of Dywity, 6 were drawn up for land parcels in the district of Różnowo, and 3 were prepared for areas lying within the district of Kieźliny. In total, they represent $2 / 3$ of all the plans in the gmina in effect at the end of 2010. This finding supports the claim that some intensive work aimed at re-zoning areas lying on the border of the city and its suburbs is in progress.

Table 3 shows that most plans in the gmina of Stawiguda, that is 13, were drawn up for the district of Bartagg (it ought to be highlighted that this is also the district adjacent to the city limits of Olsztyn in which the number of decisions on land development conditions was the lowest). Stawiguda has 7 binding plans, with 4 plans in Dorotowo.

While performing the analyses described in this article, the authors often came across a shortage of precise data regarding the coverage of plans. The lack of data from all the districts chosen for the study limited our comparative analysis to the number of binding plans, indicating data on a gminabased level.

The research results imply that the public purposes achieved through the implemented investment projects are accompanied by intensive planning work and changes in land development approved through the administrative channel, such as by passing decisions on land development conditions.

\section{Conclusions}

Local governments acting in areas surrounding urban agglomerations or urban centers with significant regional importance benefit from being located near a developing city, which stimulates their development. The migration of residents from towns to suburbs, an elevated number of investments and a dynamic real estate market exert influence on suburban areas, causing more 
intensive spatial transformations in response to the growing demands of the local residents and business investors. Building a spatial policy and planning the development of a gmina creates a challenge that suburban gminas must face, such as the shaping of spatial order. Land development means a growing demand for technical and social infrastructure, essential for new housing estates to function properly. A response to such growing expectations is good planning and the execution of public purpose investment projects (fig. 7).

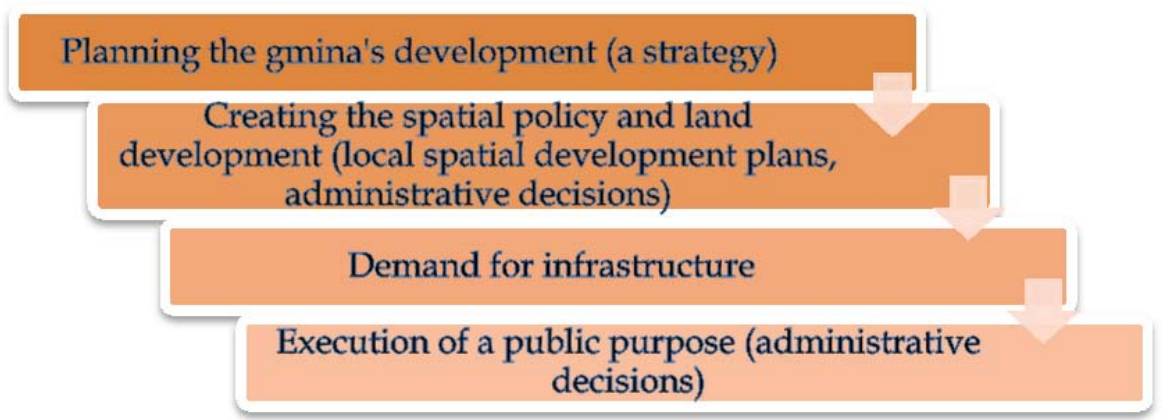

Fig. 7. Conditions underlying the execution of public purpose investment projects. Source: own study.

The analyses completed for this research demonstrate that the suburban gminas- Dywity and Stawiguda - actively create changes in the local space but also respond to the needs of residents. They do so by working hard on choosing suitable locations and enabling the execution of public purpose projects. In both gminas, during the analyzed period of time, the number of issued decisions on the location of public purpose investments was several-fold higher than the average for Poland. Most decisions concerned investments in technical infrastructure - components of electric power transmission, gas pipelines, waterworks, and wastewater and sewage systems. Fewer decisions were issued commencing investments in public buildings and facilities. The currently low contribution of decisions regarding the transportation system may soon change in response to the developing settlement in the southern part of the gmina of Dywity and in the northern and central part of the Stawiguda gmina. Local authorities should pay more attention to this sector while creating detailed procedures applicable to real estate management.

The concentration of public purpose investments in selected parts of a gmina involves spatial transformations in areas subjected to investor pressure. Thus, it can be assumed that any official approval of this type of investment projects is a response to the needs expressed by the local community and investors who arrive in the gmina. The rate and nature of this phenomenon vary both in space and in time. A specific transition zone between a town and the countryside is formed as a separate part of the suburban sphere.

\section{References}

Alterman R. 2007 The "Legitimate Public Purpose” for land expropriation. A looming crisis? Compulsory Purchase and Compensation, FIG Seminar, Helsinki

GORZELAK G., JAŁOWIECKI B., 2000 Metodologiczne podstawy strategii rozwoju regionalnego na przyktadzie województwa lubuskiego (Methodological basis of regional development strategies on the example of the Lubuskie region), "Studia Regionalne i Lokalne", Europejski Instytut Rozwoju Regionalnego i Lokalnego UW, Scholar, Warszawa, no 3/2000, p. 50

PARYSEK J. 2001 Podstawy gospodarki lokalnej (Basics of the local economy). Wyd. UAM. Poznań, pp. 213228.

PYTLAK M. 2011 Planowanie rozwoju społeczno - gospodarczego gminy - krytyczna analiza strategii rozwoju wybranych gmin zachodniego pasma aglomeracji warszawskiej (Planning socio - economic development of gmina - a critical analysis of development strategies of selected municipalities of the western band of the Warsaw agglomeration) in: "Rocznik Żyrardowski. Tom IX” red. RAKOWSKI W. pp. 339-376

SEE H. M. 2002 Regulatory expropriations in Europe: the Approach of the European Court of Human Rights N. Y. U. Environmental Law Journal. Vol. 11, No 1, pp. 136-147.

TROJANEK M. 1996 Kształtowanie atrakcyjności obszaru jako potencjalnego miejsca lokalizacji inwestycji. (Creating the attractiveness of the area as a potential investment location) W: Strategia i polityka rozwoju gmin i województw. Podstawy metodyczne, red. WYSOCKA E., Zachodnie Centrum Organizacji, 
Warszawa-Poznań- Zielona Góra

ŹRÓBEK S. ŹRÓBEK R. 2007 An assessment and proposed changes to the principals and procedures of real estate expropriation after 1945 in Poland Compulsory Purchase and Compensation FIG Workshop, Helsinki

UnITED NATIONS 2000 Taking property. UN Conference on Trade and Development. New York and Geneva.

Decision of the Provincial Administrative Court of Law of 7 March 2007, registered at IV SA/Wa 2037/06

Strategy for the Development of the Gmina of Dywity until 2020. GEOPROFIT, 2010, Warszawa

Strategy for the Development of the Gmina of Stawiguda in the years 2008 - 2015, CDEF, 2008, Olsztyn

Act of 27 March 2003 on Spatial Planning and Development. consolidated text Dz. U. of 2012 r. No 651, item 647 with subsequent amendments.

Real Property Management Act of 21 August 1997. consolidated text: Dz. U. of 2010 No 102, item 651 with subsequent amendments

Acts of 8 March 1990 r. on Local Governments in Gminas consolidated text: : Dz. U. of 2001 r. No 142, item 1591 with subsequent amendments.

www.stat.gov.pl accessed on 5.09.2012

www.kupsprzedaj.pl/Content/Maps/polska/warminsko_mazurskie/olsztynski.gif accessed

on 3.08.2012 